\title{
JCPOA; A Dialectical Paradigm of Treaty and other International Instruments
}

\author{
Nader Mardani ${ }^{1}$ \& Mohammad Mehdi Hooshmand ${ }^{2}$ \\ ${ }^{1}$ Faculty Member of School of Law and Political Sciences, Shiraz University, Shiraz, Iran \\ ${ }^{2}$ School of law and political sciences, Shiraz University, Shiraz, Iran \\ Correspondence: Mohammad Mehdi Hooshmand, School of law and political sciences, Shiraz University, Shiraz, \\ Iran. E-mail: M.Mehdi.Hooshmand@gmail.com
}

Received: March 21, 2016 Accepted: April 12, 2016 Online Published: April 27, 2016

doi:10.5539/jpl.v9n3p70 URL: http://dx.doi.org/10.5539/jpl.v9n3p70

\begin{abstract}
Generally, agreements made between subjects of international law can adopt diverse contents. Due to their status in international law system, these treaties can play different roles resulting in different repercussions. In this sense, lack of a benchmark to be used as distinguishing between treaties and other international instruments might cause problems in the system of international law of treaties because its paradigm has always been the locus of dialectic issues hold between legal scholars. JCPOA is not devoid of this dialectic since it is considered as a new pattern for solving problems in international relations. Hence, it is very important to determine the position of JCPOA in the system of international law, particularly in terms of its role within the international society, nature of subject matter, and parties. Therefore, the present study is aimed at offering an investigation of JCPOA and its comprising columns to come to an answer to the question of whether JCPOA is an international treaty or another instrument. Investigating the content of JCPOA and its comprising columns and also offering an interpretation on definition of 'treaty' from the viewpoint of1969 Convention, it is concluded that not only do not the content of JCPOA and the intentions of its writers imply a treaty, but also rules of international law of treaties and Vienna Convention confirm this too.
\end{abstract}

Keywords: JCPOA, joint comprehensive plan of action, international law of treaties, 1969convention, Iranian nuclear programme

\section{Introduction}

Advent of Iranian Nuclear Plan was in 1950 and became more serious in 1974 with the establishment of Atomic Energy Organization of Iran and signing a contract on building Bushehr Nuclear Power Plant. In 1958, Iran became a member of International Atomic Energy Agency and, in 1968, it signed the NPT; after two years approved it in Legislative Assembly ${ }^{1}$. After Islamic Revolution in 1979 Iranian Nuclear Plan remained inactive until 2003, when it was started again.

With propagation of many news about nuclear activities in Iran and after increase of disputes between Iran and some International organs such as UN Security Council, which resulted in issuance of a number of resolutions against Iranian nuclear plan, a number of sanctions were imposed on Iran by the US, UN security council, EU and some other countries. Finally during the first years of Hassan Rouhani's presidential course, negotiations came to a conclusion and Iranian 13-year old case was closed under JCPOA: an instrument between Iran and $5+1$ countries.

Due to its real position, JCPOA can play a distinguished role in imposing a discipline on their relations. This is because when mention is made of a treaty, one confronts with reign of all international laws; i.e. all functions, organs and legal structures in discipline of international law. In such conditions, the document (or the treaty) must go through the approval steps, the trustworthy party be set and attention be paid to all the points included in Vienna Convention. Moreover, document of the treaty needs to be registered in UN secretariat. In addition, the commitments included in the instrument are enforcing,whose violationwould instigate international responsibility. However, when a political agreement is concerned, such points are not obligatory or do not exist;

\footnotetext{
1- Khan, Saira (2010). "The study case:Iran". Iran and nuclear weapons. Routledge Global SecurityStudies. pp. 47-48.
} 
instead solving international issues and challenges or status of states within international relations are brought into attention.

Therefore, great importance needs to be given to the status of an agreement or document in international law which is particularly due to its related effects. It is worth mentioning that all followers of international law feel the importance of this notion and make mention of it in agreement document.

In the present study, nature of a treaty is concern from viewpoint of legal scholars and 1969 Convention. Moreover, after consideration of the difference between a treaty and a gentlemen's agreement (or other documents) and offering a number of strategies, a literature will be presented on Iranian Nuclear. Finally, legal content of JCPOA is precisely investigated in two sections, namely argumentation in analysis of JCPOA content and the parties' agreement.

\section{Concept of Treaty}

Since 1815 , i.e. the formation of Vienna Congress, the concept of treaty entered into international relations and went through great changes so far as it now is deemed as a main tool in carrying international relations. ${ }^{2}$ The two main factors of development of a treaty include writing multi-dimensional treaties and existence of international organizations, both of which play significant roles in growth and boosting the correlation between counties. Because of this, states' attempts and measure taken by official and legal, national and international (secretariats in international organizations), are of great significance. This is noteworthy because each of these institutes have constantly made attempt to come with more realistic and economical solutions. Steps involved in laws of treaties can be divided into three different periods:

First period: from 1815 to World War I

Second period: from 1919 to 1945 (World War II), the period when great liberal movement had colored the world since World War I and influenced all aspects of international dimensions; internal law was not an exception.

Third period: from 1945 up to now. In this period, international organizations adopted a peculiar concept and took effect leaps: the most importance one of which is United Nations. ${ }^{3}$

\subsection{Definition of Treaty: From the Viewpoint of Legal Scholars}

In his delicate work named “international law", QuocDinh defines 'treaty' as: the term 'treaty' incorporates whatever agreement made between two or more subjects of international law, with the aim of creating legal works". 4

Professor Charles Rousseau, the French lawman, states that: international treaty, under whatever title, is defined as a contract which is signed by subjects of international law with the aim of producing legal works.

However, Rousseau adopts meanings for international treaty: two wide and narrow. Regarding the wide sense, international treaty is only used for a set of treaties signed by main members of the international society.

In its narrow meaning, international treaty is used to define procedures involved in writing a treaty. In this respect, what is meant is 'Treaty-making power'.

From the point of view of Mc Nair, the well-known English lawman, international treaty is defined as a written agreement through which two or more international states or organizations create, or are willing to create, a relationship between themselves within the realm of international law. ${ }^{5}$

\subsection{Definition of Treaty from the Viewpoint of 1969 Vienna Convention}

One of the most salient activities of the UN is codification of rights of treaties. In 1950, General Council made International Laws Commission responsible for codifying rights of treaties. However, until 1960, the commission's activities were slow and insignificant due to the engagements it has in marine law and diplomatic securities. Nevertheless in 1961 became more serious about the issue and prepared draft of the treaty and, in 1964, sent it to states for their comments. Finally after receiving states' comments in 1966, the commission submitted final design of the treaty to UN General Assembly. Ultimately in March 1968, UN General Assembly

\footnotetext{
2 - Reuter, P., "Introduction au droit de traites", Armand colin, Paris, 1972, P.9.

3 -Falsafi, Hedayatollah, International Law of Treaties, Nashre No, Tehran, 1383, 35-46.

4- Nguyen Quoc Dinh, P. Dailler, A. Pellet, “Droit international public”, Librairie générate de Droit et de Jurisprudence, 3rd edn., Paris 1987, chapitre des traits.

${ }^{5}$ - Mc nair, The law of treaties , oxford 1961, P.4
} 
formed a conference in Vienna to discuss about this design. In two sessions (March 1968 and May 1969), the conference approved design of Vienna Treaty about laws of treaties (May $\left.24^{\text {th }}, 1969\right){ }^{6}$

Rights supervising treaties are very well explained in 1969 Vienna Convention. Undoubtedly, the 1969 Convention has made a significant job in developing rights of treaties and is considered as an influential factor in increasing this development. ${ }^{7}$ In this sense, Vienna treaty embodies a basic drawback which is ignoring many issues; and one of the most important of these issues is no presentation of a specific criterion for distinguishing between treaties and political agreements.

Clause 1 of article 2 of convention of laws of treaties define 'treaty' as follows:

Treaty is defined as an agreement between states which has been made in written form and which includes components of international law, disregard of its title; it can be reflected in a single or two or more interrelated instruments.

In this definition, treaty has been treaty has been defined as international agreement(s) in a way that it can be said that every international treaty is an international agreement, while every international agreement is not an international treaty; this is because, according to the above definition, a 'treaty' needs to have certain characteristics.

\section{Interpretation of the Concept of Treaty from the Point of View of 1969 Vienna Convention (Clause 1 of Article 2)}

\subsection{Historical Background and Negotiating History}

The first attempts to determine the common understanding of the term 'international treaty' were comparatively recent. In 1753, Emer de Vattel put down quite a modern perception: "A treaty (traite), in Latin, foedus, is a compact (pacte) entered into by sovereigns for the welfare of the State, either in perpetuity or for a considerable length of time. [...] Treaties can only be entered into by the highest State authorities, by sovereigns, who contract in the name of the State." ${ }^{.8}$ Despite early attempts to capture the term, international practice and usage combined with the language of constitutional provisions - gave the term a somewhat vague and uncertain content. ${ }^{9}$

In the late nineteenth century and early twentieth century, the academic efforts increased, culminating in the definition of the 1935 Harvard Draft Convention on the Law of Treaties. ${ }^{10}$ In addition, the registration practices of the League of Nations under Art 18 of its Covenant provided direction as to the international usage of the term 'treaty'. The registration practices of both the League of Nations and the United Nations as well as the Harvard Draft sowed the seed of the first definition in the early ILC ${ }^{11}$ proceedings. The ILC's second SR Lauterpacht focused on a treaty's "essential requirements" rather than its definition as a concept. In contrast, SR Waldock decided to refer to both 'international agreements' and 'treaties' in his Draft Art 1, using "international agreement" as the starting point for the conceptual understanding of the subject matter (definition), and "treaty" as a generic term which covers all forms and designations of an international agreement. This approach was immediately defeated by the ILC $^{12}$ mainly because it was considered 'inelegant'. ${ }^{13}$

\subsection{Designation in International Practice}

Within the realm of international relations, the variety of nomenclature for an agreement is manifold and thus confusing. Apart from 'treaty', one finds titles such as 'accord', 'act', 'convention', ${ }^{14}$ 'covenant', 15 'charter', 'declaration', 'pact', 'protocol', 'statute', 'modus vivendi', 'memorandum of understanding', 'exchange of notes/letters', 'joint communiqu e' and 'agreed minute'. ${ }^{16}$ The specific designation is seldom randomly selected

\footnotetext{
6.Falsafi, 52

7- Rebecca M. M. Wallace, Olga Martin-Ortega, “International law”, Sweet \& Maxwell, 2009, Chapter 10.

8 - Emer de Vattel, (1758), "Le droit des gens", book II ch XII Sects. 152, 154 (CG Fenwick translation (1916) 160).

9 - Harvard Draft 667.

${ }^{10}$ - Harvard Draft 657, Art 1 lit a: "A 'treaty' is a formal instrument of agreement by which two or more States establish or seek to establish a relation under international law between themselves."

11 - International Law Commission

12 - Yearbook of the International Law Commission 49, (1962), I , paras 52.

13 - Ibid, 61.

14 - Art 38 para 1 lit a ICJ Statute.

15 - the 1966 International Covenant on Civil and Political Rights 999 UNTS 171.

16 - DP Myers, (1957), “The Names and Scope of Treaties”, American Journal of International Law, No.51, P. 574.
} 
by the participating parties ${ }^{17}$ : terms such as 'exchange of letters' indicate - contrary to 'covenant' - the less formal character of the agreement; the title 'declaration' may suggest that no legally binding effect is intended. Nonetheless, one must be extremely careful when assessing the status of an instrument solely based on its title. ${ }^{18}$ The provisions of the agreement, the particular circumstances in which it was drawn up, as well as the intention of the parties may disprove the prima facie suggestion communicated by a designation. ${ }^{19}$

\subsection{Governing Law}

Treaties must be governed by international law in order to fall within the scope of the Convention. The phrase denotes the body of law applicable - i.e. all sources enumerated in Art 38 ICJ Statute ${ }^{20}$ - when executing and interpreting the treaty (e.g. all questions relating to validity, binding force, ${ }^{21}$ effect, application and termination) and the body of law to be used when resolving any treaty-related dispute (e.g. the law of State responsibility). The requirement serves to distinguish between international agreements regulated by public international law and those which, although concluded between States, are regulated by the national law of one of the parties or by some other national law system chosen by the parties by virtue of a choice-of-law clause (proper law).

See e.g. the loan agreements concluded by Denmark with Jordan, Brazil, Iran and Malaysia which contain an identical Art XII: "Unless otherwise provided for in the Agreement, the Agreement and all the rights and obligations deriving from it shall be governed by Danish law."

As a rule, the legal system which provides the agreement with binding force is not necessarily identical to the legal system chosen to govern the provisions of the agreement. ${ }^{22}$ To come within the definition of 'treaty' and accordingly within the scope of the VCLT, however, interstate treaties must be both binding under international law and (at least partly) subjected to international law. ${ }^{23}$

When drafting Art 2 para 1 lit a, the ILC discussed whether the phrase 'intended to be governed by international law' would be preferable, in order to indicate that the proper law of an agreement depends on the will of the parties alone. The ILC's final decision to abandon the words 'intended to be' was based on the presumption that the phrase "governed by international law" embraces the intent relating thereto. There was, however, the strong opinion that, depending on the subject matter of the respective agreement, the freedom of States Parties to choose the proper law is limited by international law. In view of international treaty practices, it was, and still is, undisputed that States are at liberty to choose domestic law - or international law - as the proper law if the subject matter of the agreement is of a commercial nature, ie relating to loans, trade of goods, guarantee of interest, the lease of buildings or the exchange of patents (pacta iure gestionis). ${ }^{24}$ Contrary to the ILC's suggestion, however, it is questionable whether States are legally obliged to subject their agreements to international law if the latter affect the sovereign sphere of the parties or contain transactions of a sovereign character (pacta iure imperii). Whereas national legal systems know limits of the choice-of-law principle 'l'autonomie de la volont e' due to public policy, comparable international rules are difficult to detect. Therefore, the issue should be solved in a practical rather than a dogmatic manner. If the selected municipal law appears to be - partially - inappropriate and ineligible with regard to the subject matter (eg the transfer of territorial sovereignty contrary to real estate), international law as the 'proper law' would fill the gaps.

If States exercise their 'autonomie de la volont e' in an abusive way, eg in order to escape ius cogens obligations (Art 53) or obligations under the UN Charter (Art 103 UN Charter; Art 30), the conflicting international obligations of the contracting parties remain unaffected on the international plane, just as they remain unaffected in the case of inconsistent national legislation (Art 27). ${ }^{25}$ An institution entitled to settle a contract-related dispute, however, may refuse to apply the national law governing the interstate contract if the consequences of

\footnotetext{
17 - JK Gamble, (1980), "Multilateral Treaties: The Significance of the Name of the Instrument”, Interdisciplinary Law Journal, Vol.10, California Western.

18 - ICJ South West Africa Cases (Ethiopia v South Africa, Liberia v South Africa) (Preliminary Objections) [1962] ICJ Rep 319, 331.

19 - ICJ Aegean Sea Continental Shelf (Greece v Turkey) [1978] ICJ Rep 3, para 96.

20 - JW, (1996), "Head Evolution of the Governing Law for Loan Agreements", American Journal of International Law, No.90, P.214227.

21 - M. Fitzmaurice, \& O. Elias, “Contemporary Issues in the Law of Treaties”, Netherlands, Eleven International Publishing, 2005 , p. 20.

22 - Seidl-Hohenveldern, Ignaz, (1975), “The Theory of Quasi-International and Partly International Agreements”, Revue Belge de Droit International, no. 11, P. 567.

23 - M. Fitzmaurice, \& O. Elias, Op. Sit., P. 21.

24 - Harvard Draft 694.

25 - S Michalowski/JP Bohoslavsky, (2009), "Ius cogens, Transnational Justice and Other Trends of the Debate on Odious Debts: A Response to the World Bank Discussion Paper on Odious Debts", Columbia Journal of Transnational Law, Vol. 48, P.59.
} 
that application would be contrary to international ius cogens obligations. The consent to subject an agreement to a domestic legal system can be implicitly expressed, elucidated by the subject of the agreement, the process of conclusion, the State organs involved and the place of performance. In a case where the States Parties do not explicitly or implicitly choose domestic law as the proper law of their agreement, it is assumed that the agreement is governed by international law regardless of its content. ${ }^{26}$ In some cases, agreements between States and/or international organizations are governed in some respects by international law, in other respects by the law of a particular State.

Cf the 2009 Framework Agreement on Integrated Cross-Border Maritime Law Enforcement Operations between the Government of the United States of America and the Government of Canada ('Shiprider Agreement'), Art 11 para 2: "Any claim submitted for damage, harm, injury, death and loss resulting from an integrated cross-border maritime law enforcement operation carried out by a Party under this agreement shall be resolved in accordance with the domestic law of the party to which the claim is brought and with international law."

See also the 1950 Loan Agreement between Iraq and the IBRD, where it is stated in Art X \} 1 that "the respective rights and obligations of the parties hereto under this Agreement [. . .] shall be valid and enforceable in accordance with their terms anything in any statute, law or regulation of any nation or state [...] to the contrary notwithstanding". Even so, Art X $\} 2$ determines that "the provisions of this Agreement [. . . ] shall be interpreted in accordance with the law of the State of New York, United States, as at the time in effect".

Such hybrid agreements can be considered treaties "governed by international law" because they are, in principle, subjected to international law as the fundamental legal regime common to both parties. Isolated treaty provisions deviant thereto, while referring to municipal law for certain purposes, do not frustrate the application of the VCLT. $^{27}$ When the ILC discussed the parallel provision of the VCLT II, the question arose as to whether the Convention should be applicable if an agreement between an international organization and one of its Member States is subjected to the internal rules of the international organization.

In order to exclude agreements governed by the internal law of an international organization from the scope of the 1986 Convention, SR Reuter suggested the phrase "governed by general international law". The ILC has rightly rejected this addition since - unlike municipal law - the internal rules of an international organization cannot be strictly segregated from international law. International law - e.g. Art 53 VCLT (ius cogens) - governs the constituent instrument of an international organization and consequently its derivative internal rules. Therefore, an agreement subjected to the internal rules of an international organization is ultimately governed by international law.

\subsection{Intention to Establish a Legal Relationship}

Even if the final wording of Art 2 para 1 lit a does not reflect the necessity of the parties' intention to establish a legal relationship, the respective consensus ad idem ${ }^{28}$ still constitutes a decisive element in order to characterize treaties as being different from political instruments: no will, no law. Contrary to the ILC, the States quite broadly discussed the phrase 'intended to create rights and obligations' as a desirable amendment to Draft Art 2. The Drafting Committee, however, emphasized that the phrase 'governed by international law' would embrace the element of intent and thus rejected the amendment. ${ }^{29}$

As a general rule, the parties must intend to create a legally binding instrument comprising rights and obligations in order to conclude a 'treaty' in terms of the VCLT. Such legal rights and obligations necessarily correspond, i.e. the obligations incumbent on one subject always match the right of the other subject (correlation of rights and duties). ${ }^{30}$ On the other hand, the agreed rights and obligations need not be equally distributed among the parties. Moreover, the compliance structure of the treaty does not have to be reciprocal. In some cases, the parties'

\footnotetext{
26 - GR Delaume, (1962), “The Proper Law of Loans Concluded by International Persons", American Journal of International Law, No.56, P. 63-76.

27 -Vienna Convention on the law of the treaties

28 - Widdows, K., (1979), “What Is an Agreement in International Law?”, British Yearbook of International Law, No.50, P.117.

${ }^{29}$ - Waldock I 31. See the criticism of Austria [1965-II] YbILC 10 and the amendments proposed by Chile UN Doc A/CONF.39/C.1/L.16, and Malaysia and Mexico UN Doc A/CONF.39/C.1/L.33 and Add.1, UNCLOT III 111; for a comprehensive overview of the discussion, see Klabbers

$58-62$.

${ }^{30}$ - SR R Ago Second Report on State Responsibility [1970-II] YbILC 192 para 46.
} 
consent does not produce tangible legal rights and obligations; nonetheless it amounts to a 'treaty' in terms of the VCLT if the parties' will establish or affects a legal relationship in a broader sense. Some treaties derogate pre-existing international rights and obligations; others authoritatively reinterpret a preceding treaty but are treaties in themselves. If a document, however, gives a mere account of the discussion and a summary of facts, considerations, explanations and statements rather than commitments, it constitutes a simple record of a meeting without being a treaty. The element 'intent to establish a legal relationship' is crucial for the distinction between legally binding treaties and non-binding instruments. If the parties have not made their intention to enter into legal relations - or the lack of such intention - explicit (e.g. with a ratification clause ${ }^{31}$ ), the determination of the legally binding character of the respective instrument has to be based on indications. ${ }^{32}$

The ICJ decided on intention with view to the drafting history, the language of the agreement and the circumstances of its conclusion as well as the subsequent practice (e.g. documents submitted for registration under Art $102 \mathrm{UN}$ Charter). In contrast, the designation and the form of the act as well as the failure to register were considered irrelevant. The same holds true for the presence of signatures since it does not necessarily denote a legally binding consent (Cf the 1975 Helsinki Final Act).

If the intent of the parties to be legally bound under international law cannot be determined on the basis of objective criteria, it has to be assumed that no legal relations have been established. ${ }^{33}$ If the scrutiny of all objective criteria reveals that some parties to a multilateral instrument have considered it a legally binding treaty whereas the other participants have lacked the intention to establish a legal relationship, it has to be determined whether treaty relations have been established between the former groups. The question has to be answered in the affirmative unless the intended distribution of rights and obligations among the participants necessarily demands the participation of the latter group in the treaty. If the requirements of Art 48 are met, a party to the former group may invoke an error in order to invalidate its consent to be bound by the treaty.

\subsection{Non-legally Binding Agreements}

The terms commonly used to capture the character of non-legally binding agreements vary: 'soft law', 'extra-legal commitment', 'gentlemen's agreement', 'de facto agreement', 'non-treaty agreement', 'political commitment' or 'informal understanding'. The same holds true for their official designation: 'declaration', 'statement', 'guideline', 'recommendation' or 'Programme' are just a few among many designations selected by the parties to accentuate the non-legal character of the instrument. The name, however, neither determines the status nor the effects of the instrument (! MN 5). The reasons to opt for a non-legally binding instrument may be manifold (eg simplicity, secrecy or necessity) but are, reducible to the primacy of leeway over legal certainty. A much discussed but somewhat academic systematization of non-legally binding agreements has been introduced by Eisemann ${ }^{34}$ : whereas "accords informels politiques" are to be programmatic in character, "accords informels suppletifs (interpr etatifs)" serve to prevent a procedural paralysis within organs of international organizations. Finally, the States agree on "accords informals normatifs" when regulating their future conduct in a treaty-like but informal manner. As is the case with the term 'soft law', the latter category institutes a law making process without substantiating it. It is undisputed that non-legal instruments produce the political or moral obligation for the participating States to perform their mutual commitments. No different from treaties, the willingness to perform these non-legal commitments depends strongly on their reciprocal (self-) interest. Contrary to treaties, the neglect of political commitment must not entail countermeasures (reprisals) according to the law of State responsibility but may yield unfriendly but lawful responses (retorsions). The distinction between non-legal agreements between States and true gentle men's agreements has more historical value than actual importance: the latter are to be personal pledges of honor given by the official in his or her private capacity but yet closely related to his or her political position, influence and fate. If the expectations in the officials' actions are belied, no retaliatory acts may be taken against the official's State other than unfriendly but lawful responses (retorsions).

There is strong disagreement among scholars whether non-legally binding agreements can produce legal consequences via the principle of estoppel. ${ }^{35}$ If a State relies upon mutual but non-legal commitments and takes proper actions, the question arises whether the State's confidence in the other State's compliance or the other States' confidence in the continuance of actions is worthy of legal protection. It is not so worthy if the intention

\footnotetext{
31 - Fawcett, (1953) “The Legal Character of International Agreements”, British Yearbook of International Law, No.30, P. 381,

32 - Aust, A., (1986), “The Theory and Practice of Informal International Instruments”, International \& Comparative Law Quarterly, Vol.35, P.787.

33 - UN Treaty Handbook (2001) para 5.3.4: "clear on the face of the instrument".

34 - PM Eisemann Le, (1979), “'Gentlemen’s Agreement’ comme source de droit international”, JDI, vol.106, P. 326, 331-338.

35 - Eisemann (n 122) 347
} 
of both States to create a non-legally binding instrument can be established. In that case, all participating States are aware that none of them is legally estopped from changing the conduct; their remaining discretionary powers are unfolded. Therefore, the existence of a non-legally binding agreement does rather oppose the operation of the estoppels principle more than support it. However, non-legally binding agreements may shape consent for future treaties. If the participating parties change their opinio iuris, a non-legally binding agreement may generate a feeling of necessity (opinio necessitatis) and lead to custom. There are a few cases in which international courts and tribunals have applied 'soft law', most of them non-binding resolutions of international organizations. ${ }^{36}$ An exceptional example for the judicial application of a non-legally binding agreement between States is the Charter on Fundamental Rights of the European Union, referred to by the ECJ in order to emphasize the importance of certain human rights within the EU legal order. This approach represents the characteristic of most international decisions that consult soft law instruments: non-legally binding principles are exploited to unveil the content of treaty or custom, i.e. traditional sources of international law.

\section{Distinguishing between Treaty and Gentlemen's Agreements and Other Instruments}

Notwithstanding similarities between the law of treaties in international law and that of contract in municipal law systems, it is important to bear in mind some fundamental difference between legal systems operating on the international and on the national planes that are relevant to the distinction between binding and non-binding international agreements. The first is the relative importance in international relations of structured, relatively formal, and often continuous relations between states, which take many forms ranging from relations between government departments, through diplomatic relations, to meeting of heads of state, some of which are not intended in themselves to have, and do not have, specific legal consequence. This factor in international relations, which has led to the increased user and importance of non-binding informal instruments, has no real equivalent at the national level.A second factor operating at the international level is the use made, in the absence of any international legislative body, of agreements to achieve objectives, which at the national level, would generally be achieved through legislation. This has given rise, among other things, to the growing importance of international instruments that are negotiated and drafted in ways virtually indistinguishable from binding treaty instruments, but which are not intended to be, and are not, legally binding. They may eventually become binding, either through their influence on the formation of customary international law or through their eventual incorporation into a binding treaty; and they are often intended to do so. These are often, and perhaps confusingly, called "soft-law" instruments. ${ }^{37}$

According to the concept of gentlemen's agreements, it is obvious that gentlemen's agreements require relationship and refer to future behavior. ${ }^{38}$ Agreement requires relationship and this relationship often would be verbal, either oral or written. On this basis, one-dimensional statements are excluded from agreement. Agreements must refer to future behavior and have effect(s) on future relationships between the parties. Hence, every joint statement or multi-dimensional instrument cannot be deemed an agreement. These two criteria are necessary in treaties. Although these qualitative differences exist within the nature of expectations from future behavior, many forms, structures, regulations, and even exiting rules are employed the same as treaties in these agreements because of the development of gentlemen's agreements ${ }^{39}$. Therefore, parties' intention is the distinguishing factor in international law. Undoubtedly, this be due to basics of voluntarism in international law.

International court of justice boost the importance of parties' intention in determining the nature of an international instrument and independency of intention from shape. It seems that the court is not a locus where international law implements harsh and precise conditions. ${ }^{40}$ The court believes that, as common in international law, international law does not enforce a certain shape when focus is on parties' intention. Parties are free to choose whatever shape that expresses their intention. ${ }^{41}$ So, the main criterion is whether any specific instrument makes parties' intention clear for creation of enforcing legal laws. ${ }^{42}$

In previous works of international law writers, focus has been put on the role of parties' intentions in determining whether international agreements are legal or not. For example, Fawcett claims that the most important element

\footnotetext{
36 - Klabbers, J., (1996), “The Redundancy of Soft Law” 65 Nordic JIL, 167, 172-174.

${ }^{37}$ - M. Fitzmaurice, \& O. Elias, "Contemporary Issues in the Law of Treaties", Netherlands, Eleven International Publishing, 2005, p. 6.

${ }^{38}$-J. Klabbers, "The Concept of Treaty in International Law", Netherlands, Kluwer Law, 1998, p. 53.

${ }^{39}$-D. B. Hollis, \& J. J. Newcomer, "Political Commitments and The Constitution”, Virginia Journal of International Law, 2009, vol. 49, no.

3, p. 522 .

${ }^{40}$-Nuclear Tests Cases (Australia v. France and New Zealand v. France), ICJ Reports, 1974, pp. 267-268.

${ }^{41}$-Temple of PreahVihear Case (Cambodia v. Thailand), ICJ Reports, 1961, p. 34.

${ }^{42}$-Aegean Sea Continental Shelf Case (Greece v. Turkey), ICJ Reports, 1978, pp. 39, 44.
} 
in an enforcing international law agreement (compared to political commitments) is parties' intention in creating legal commitments for themselves. ${ }^{43}$ OppenheimInternational Law puts the focus on parties' intention too: still, the decisive factor is whether the instrument has the aim of creating international laws and commitments between the parties or not. This is what, as Commission of International law believes, exists in the expression "including international law". ${ }^{44}$ Moreover, in its Directive in 1983 with title of "international texts with legal importance in their mutual relationships between the writers and texts without this legal importance", International Law Institute also notes the role of intention. In clause 4 of this, it can be seen that: "texts including commitments whose accepting states have the intention of being obligated at the political level, and maintain all their works at that level (and in this sense be known as political treaties) cannot be considered as important legal texts".

In its $8^{\text {th }}$ clause, mention has been made of the role of intention is determining legal or political characteristic of an international text whose legal nature is not certain. ${ }^{45}$ Analysis of part 1 of clause 1 of article 2 of 1969 convention of treaties laws indicate that factor of intention is very important in distinguishing between different agreements. In defining treaty, the convention uses the term "includes international law". Comments out by reporters' commission of international law needs to be investigated in this regard. Some scholars have not used the term "includes international law" but, instead, they have used the term "creating a relationship based on international law". ${ }^{46}$ Though Lauterpacht did not propose a comprehensive definition of treaty, he made attempts to incorporate the notion of "creation of legal commitments and acceptance of commitments with legal feature from both parties' as an elements in defining 'treaty'. ${ }^{47}$

This legal commitment is an element which separates a treaty from a political (gentlemen's) instrument. This line of claims was followed by Fitzmaurice. In different drafts, he noted creation of legal or creation of an including relationship of international law. According to him, treaties are in themselves included in international law provided that they be written with the intention of creating legal law and legal commitments or creation of relations. ${ }^{48}$ The commission preferred to disregard the inclusion of 'intention' in its definition due to a number of reasons. Firstly, inclusion s the term would imply that states can always choose from among legal systems while this is not always possible. Territory hierarchies are must be followed by international law, disregard of the intention. According to Yasin, states can selected whether the agreement made by them be a function of international law or state's law, as far as this choice is allowed by international law. Here, he mentions agreements related to state's seas. ${ }^{49}$ Another reason was that a number of commission members believed that nature of treaty parties necessarily includes an inter-states agreement in the first place. Finally, the commission came to the conclusion that 'intention' is hidden in the expression "includes international law" and there is no need to mention it in the definition of treaty. Thus, according to international law commission, the expression "includes international law", the element of 'intention' covers creation of rights and commitments in international law. Investigation of work and interpretation of the commission about this article shows that intention is useful for distinguishing between different agreements; in one hand, for distinguishing between obligatory legal agreements and gentlemen's agreements and, one the other hand, for distinguishing between agreements included in international law and those included in state's agreements except for those case where states do not have the right to choose. Regarding the former, intention cannot have any role.

According to problems of subjectivity, one needs to explore in what way understanding of this intention must be carried out. How do states make their intentions clear for creating a gentlemen's agreement? As it will be discussed, in topics such as Aegean Sea Continental Shelf and Qatar against Bahrain, the court noticed concrete realizations of intention. This intention can be proved through interpretations including investigation of terms and expressions employed in the text, the atmosphere in which the text has been accepted, states' future behavior and other similar symptoms.

\subsection{Expression of Intention in Instrument}

States might clearly note this intention in their agreement in written form. For example, in introduction to

${ }^{43}$ - J. Fawcett, "The Legal Character of International Agreements", BYIL, 1953, vol. 30, p. 385

${ }^{44}$-R. Jennings, \& A. Watts, (eds), “Oppenheim's International Law”, vol. 2 (9th ed), London, Longman, 1996, p.1202.

${ }^{45}$-IDI , International Texts of Legal Import in the Mutual Relations of Their Authors and Texts Devoid of Such Import, Session of Cambridge, 1983

${ }^{46}$-Yearbook of the International Law Commission (1950),vol. II, p. 226

${ }^{47}$-Yearbook of the International Law Commission (1953), vol. II, p. 90.

${ }^{48}$-Yearbook of the International Law Commission (1956), vol. II, p. 117

${ }^{49}$-Yearbook of the International Law Commission (1962), vol. I, p. 52 
Stockholm's Disarmament Declaration, agreement is described as a political necessity. In some cases, the text might falsify whatever intention for creation of any obligatory legal instrument.

\subsection{Shape and Name}

It is obvious that neither shape nor names of an instrument can solely have a determining role in its legal nature, because international law is not a formalistic system. Despite this, through investigation of the shape and phraseology of the instrument, one can figure out parties' intentions toward position of the instrument. In England's procedure, using terms such as 'shall', 'agree', and 'enter into force' denote the intention to make a treaty. On the contrary, using 'will' instead of 'shall', no employment of terms such as 'undertake' and 'agree' or expressions such as 'come into effect' or 'come into operation' and naming the instrument a 'memorandum' or similar titles can imply the intention of creating gentlemen's agreement. ${ }^{50}$

Regarding method of text writing and employing terms and expression, similar points to those in England's procedure can be observed in instruction of US State Department. This instruction primarily states that it is better for both parties to confirm that their memorandum is an instrument incorporating enforcing commitments which is not based on international law; or in the falsifying text, it is set that the mentioned instrument is not required to be entered into force based on international law. In this instruction, other than similar points to those in England's procedure, it is recommended to negotiators of no-enforcement instruments to avoid using words 'parties', 'agreement' and 'treaty'. But, it alarms that mere calling the instrument a memorandum does not in itself imply that the instrument is no-enforcement for the state in terms of international law. Since enforcement instruments might be written in different languages, the instruction recommends that the sentence must not be included in these instruments so that different texts would have equal value. ${ }^{51}$

Although procedures of many states are the same as that of England, England has been more precise and stable in its phraseology. ${ }^{52}$

In Iranian bylaw of how to make international agreements, special attention has been paid to the notion that memorandum is a gentlemen's agreement in article 1. Moreover, other terms have been named as gentlemen's agreements in article 16 stating that Iranian state organizations are required to use certain terms if they intend to write a gentlemen's agreement. These terms include memorandum, resolution, statement, recommendation letter, inventory, parliament document. In clause 1 of this article, it has been put forward that: "state organizations are not allowed to titles such as convention, concord, agreement, contract, and compact for gentlemen's agreements, and these can be used for legal procedural agreements".

\subsection{Terms in the Text and Atmosphere of Making the Contract}

With regard to general rules of interpretation and procedure of international court of justice, legal obligation intention can be extrapolated from real terms in the text, i.e. language of the text and the atmosphere of the time of making it. In case of Aegean Sea Continental Shelf, regarding the Joint Declaration claimed by Greece, the court stated that shape is not determining and that a joint statement can serve as an enforcing letter so as to refer a case to arbitration. In this sense, the count believes that, regarding nature of a specific instrument and its measures, attention needs to be paid to its real terms and the atmosphere under which the instrument has been written. ${ }^{53}$

So, the court analyzed the joint statement in terms of its specific language and the contents of negotiations in 1975. In case of Qatar against Bahrain, the court repeated preliminary measures of its verdict in Aegean Sea: "before anything, real terms and the atmosphere in which the instrument has been written must be noticed" 54

It is understood from procedure of the court that if one can reach legal or illegal nature of the instrument through the investigation of instrument's nature or the conditions that lead to it, the discussion is well closed. Only where the text is vague, depending on other symptoms is justifiable. ${ }^{55}$ The directive of international law institute delineates that: "legal texts are those texts whose writers agree on making a revision or termination of legal

\footnotetext{
${ }^{50}$ - A. Aust, "The Theory and Practice of Informal International Instruments", ICLQ, 1986, vol. 35, no. 4, p. 800.

${ }^{51}$ - U.S. Department of State, Guidance on Non-Binding Documents, http://www.state.gov/s/1/treaty/guidance

52 - A. Aust, op. cit.

${ }^{53}$ - ICJ Reports, 1978, p. 39, para. 96.

54- Maritime Delimitation and Territorial Questions Between Qatar and Bahrain (Qatar v. Bahrain), ICJ Reports, 1994, p. 120, para. 23.

${ }^{55}$ - Maritime Delimitation and Territorial Questions Between Qatar and Bahrain (Qatar v. Bahrain), ICJ Reports, 1994, p. 120, para. 23.
} 
compacts. Also, legal texts are those text whose writers are after creating a legal framework for parties' future actions or creating elements or institutional functions, most probably at non-legal levels ${ }^{\prime \prime 56}$ This means that the directive necessitates attention to content of the texts and to terms used for distinguishing between legal and illegal texts.

Regarding texts, two points need to be taken into consideration. First, content of instrument or subject matter is a not a fair guide to detect parties' intentions. This is because a subject matter might be included both in treaty instruments and in those which are not deemed a treaty. However, a noteworthy exception is those instruments which propose dispute resolution between the parties through an international judicial method. ${ }^{57}$ Secondly, in analysing a text, generalizations and impreciseness of expression must not be overemphasized, nor should this be a criterion. Because, generalization and impreciseness are observed both in treaties and in gentlemen's treaties, too. If the criterion of preciseness is to be precisely employed for all the treaties, it must be taken into account that many of them have regulations with no legal effects. Treaties that are made in the realm of cultural cooperation or treaties on friendship and trade with generalized definitions on parties' joint intention and goals are included among these treaties too. Even in United Nations Charter and statues of international organizations, some instances of such terms can be observed, such as articles 55 and 56 of the charter.

\subsection{Other Symptoms}

Other symptoms are related to actions which have been done after the instrument was written. States' future behavior is having the instrument registered in the UN secretariat or publishing it in the international level; they need to note whether the agreement has been described as a treaty or a legal agreement in national parliaments or courts. ${ }^{58}$ However, none of these actions can solely be deemed as decisive reason, but they need to be evaluated by the related language of instrument. For example, although making an instrument registered in UN secretariat based on article 102 of the charter is a good evidence of the notion that parties know the instrument as a treaty, this is not always the case. It seems that procedure of UN secretariat is that more or less it makes whatever it receives registered. On the other hand, failure to have a treaty registered does not harm it position as a treaty, even if it cannot be relied on by UN elements. ${ }^{59}$ Ultimately, regarding detection of the intention, one can depend on the problem of assumption. When states write an agreement according to which it is not clear whether it is a treaty or gentlemen's agreement, should we assume it a treaty instrument or a gentlemen's one?

It is understood from interpretation of the commission that when parties are states, since states' actions basically follow system of international law at the international level, unless they have a different intention, the assumption is that the written agreement is a treaty in terms of the nature of an international agreement. Up to now, most international lawmen have supported the assumption that agreements are treaties not gentlemen's ones. ${ }^{60}$

In states' procedures, this assumption can be observed. For example, rules of US Ministry of Foreign Affairs state that "in lack of an obvious nature of an international agreement, it is generally assumed that this agreement is enforcing in terms of law. On this basis, it become clear through clear reasons including investigation of the history of negotiations or other ways that parties had the intention of being followers of another system, this assumption is disregarded". ${ }^{6}$

\section{A Summary of Iranian Nuclear Plan}

The nuclear program of Iran has included several research sites, two uranium mines, a research reactor, and uranium processing facilities that include three known uranium enrichment plants. ${ }^{62}$ Iran has signed treaties repudiating the possession of weapons of mass destruction including the Biological Weapons Convention ${ }^{63}$ and the Chemical Weapons Convention. ${ }^{64}$ It also ratified the Nuclear Non-Proliferation Treaty (NPT) ${ }^{65}$ making its nuclear program subject to International Atomic Energy Agency (IAEA) verification.

\footnotetext{
${ }^{56}$ - IDI, op. cit.

${ }^{57}$ - Fawcett, J, op. cit., pp. 387-388.

58 - O. Schachter, op. cit., p. 298.

${ }^{59}$ - Aust, op. cit., p. 803.

${ }^{60}$ - D.B. Hollis, \& J. J. Newcomer, op. cit., p. 524.

${ }^{61}$ - M. J. Garcia, "International Law and Agreements: Their Effect Upon U.S Law", Congressional Research Service, http://www.fas.org/sgp/crs/misc/RL32528.pdf(2010),

${ }^{62}$ - Kerr, Paul k., "Iran's Nuclear Program: Status", Congressional Research Service, Retrieved 2 October 2012.

${ }^{63}$ - "Signatories of the Biological Weapons Convention", Retrieved 23 November 2011, at: http://www.opbw.org/convention/status.html

${ }^{64}$ - Retrieved 22 July 2008. At:https://www.opcw.org/about-opcw/member-states/
} 
The program was launched in the 1950s with the help of the United States as part of the Atoms for Peace program. ${ }^{66}$ The participation of the United States and Western European governments in Iran's nuclear program continued until the 1979 Iranian Revolution that toppled the Shah of Iran. ${ }^{67}$ Following the 1979 Revolution, most of the international nuclear cooperation with Iran was cut off. In 1981, Iranian officials concluded that the country's nuclear development should continue. Negotiations took place with France in the late 1980s and with Argentina in the early 1990s, and agreements were reached. In the 1990s, Russia formed a joint research organization with Iran, providing Iran with Russian nuclear experts and technical information.

In February $9^{\text {th }}, 2003$, the president Mohamad Khatami published a news on provision of nuclear power plant fuel by Iranian specialists. In April 2006, the president Mahmud Ahmadinejad said that Iran has Uranium enrichment to $3.5 \%$. In February $15^{\text {th }}$, 2012, Iran talked of making $20 \%$ enriched fuel rods and their placement in 5 Mega Watt research reactors in Tehran. With propagation of many news about nuclear activities in Iran and after increase of disputes between Iran and some International organs such as UN security council, which resulted in issuance of a number of resolutions against Iranian nuclear plan, a number of sanctions were imposed on Iran by the US, UN security council, EU and some other countries.

In the 2000s, the revelation of Iran's clandestine uranium enrichment program raised concerns that it might be intended for non-peaceful uses. The IAEA launched an investigation in 2003 after an Iranian dissident group revealed undeclared nuclear activities carried out by Iran. ${ }^{68}$ In 2006, because of Iran's noncompliance with its NPT obligations, the United Nations Security Council demanded that Iran suspend its enrichment programs. In November 2011, the IAEA reported credible evidence that Iran had been conducting experiments aimed at designing a nuclear bomb until 2003, and that research may have continued on a smaller scale after that time.69

\section{Argumentation in Analysis of JCPOA Content}

Paragraph 1 of preface to $\mathrm{JCPOA}^{70}$ clearly states that this instrument is a statement of a country's peaceful nuclear actions. Also, it states Iran's no intention of reaching nuclear weapons. This is discovering a situation, not creating it. In other terms, it demonstrates that Iran has been faithful to its commitments within the framework of internal law and international treaties. Therefore, this instrument does not make Iran committed to international rules and international treaties; but instead Iran has been faithful to its international commitments in advance.

In the second paragraph of the preface to $\mathrm{JCPOA}^{71}$, one can see a situation being discovered and not creating it. But, there exists a condition and it is following JCPOA. Maybe, at the first look it is assumed that development of Iranian peaceful nuclear activity within the JCPOA framework is an international liability. However, enforcement of these commitments does emerge from JCPOA instrument, but this enforcement emerges from 2231 resolution, which will be elaborated on in the following sections.

Although clause 1 of the preamble and general provisions imply mutual commitments for the two parties, it requires to be confirmed by the UN. In other terms, this instrument is attached to UN resolution. Before these negotiations, Iran was included in chapter 7 sanction resolutions and started negotiations for terminating and devaluing previous sanctions, whose results was preparation of UN 2231 resolution; in fact JCPOA is attached in the resolution. Therefore, what has happened is negotiation for preparation of the draft of $\mathrm{UN}$ resolution. Hence, although mutual commitments of both parties have been characterized $n$ JCPOA, this is a mere plan and view of these mutual duties and enforcement of provision of JCPOA does not emerge from the instrument itself but from

\footnotetext{
65- Retrieved 17 April 2006. At: https://fas.org/nuke/control/npt/text/npt3.htm

${ }^{66}$ - Roe, Sam, "An atomic threat made in America", Chicago Tribune, January 28, 2007.

${ }^{67}$ - "Iran Affairs: Blasts from the Past: Western Support for Iran's Nuclear program". 2008. Retrieved 24 February 2008. at: http://www.iranaffairs.com/iran_affairs/2006/05/blasts_from_the.html

${ }^{68}$ - "IAEA GOV/2003/40: Implementation of the NPT safeguards agreement in the Islamic Republic of Iran", Retrieved 20 September 2009.

69 - "IAEA Report for military dimensions, see pages 4-12", International Atomic Energy Agency. 8 November 2011. At: http://www.isis-online.org/uploads/isis-reports/documents/_AEEA_Iran_8Nov2011.pdf

70 _. The E3/EU+3 (China, France, Germany, the Russian Federation, the United Kingdom and the United States, with the High Representative of the European Union for Foreign Affairs and Security Policy) and the Islamic Republic of Iran welcome this historic Joint Comprehensive Plan of Action (JCPOA), which will ensure that Iran's nuclear programme will be exclusively peaceful, and mark a fundamental shift in their approach to this issue. They anticipate that full implementation of this JCPOA will positively contribute to regional and international peace and security. Iran reaffirms that under no circumstances will Iran ever seek, develop or acquire any nuclear weapons."

71 - "Iran envisions that this JCPOA will allow it to move forward with an exclusively peaceful, indigenous nuclear programme, in line with scientific and economic considerations, in accordance with the JCPOA, and with a view to building confidence and encouraging international cooperation. ..."
} 
the 2231 resolution itself.

The main reason for such classification is part 34 of JCPOA (the implementation plan) and its clauses. ${ }^{72}$

One of the most important elements of the day is submission of JCPOA resolution to UN. Moreover, day of agreement was an important turning point in time, which took place 90 days after the confirmation of JCPOA by the UN resolution. Basically, start of providing the necessary arrangements for the implementation of JCPOA is basically relied on approval of the resolution. In addition, day of implementation of the resolution is the day of start of commitments by the UN and USA (though some think commitments happen in the day of transference, i.e. 8 years after the day of agreement, or the day when UN Security Council is terminated) and this is dependent on report of the agency. As can be seen, although this instrument and its implementation is an attachment to the resolution, it is in fact a plan and method for management of Iran' peaceful nuclear plan. Regarding this, argumentation is the most important reason of the final clause of section 34 .

Further, clause "II" of the preamble and general provisions ${ }^{73}$, which talks about guaranteeing the peaceful nature of Iranian nuclear plan, indicates the discovering sense of this instrument. Even clause "III" of the preamble and general provisions ${ }^{74}$ is a promise based on NPT and is repeated in JCPOA, while it does not repeat itself. Nevertheless, this affirmation is clear from the text, it is constant affirmation and will exist in future too.

Clause "XIV" of preamble and general provisions ${ }^{75}$ obviously states that JCPOA has a treaty nature and that the text at the end of JCPOA and general provisions, written in a different form, is not a treaty:

"Iran and E3/EU+3 will take the following voluntary measures within the timeframe asdetailed in this JCPOA and its Annexes"

However, this treaty includes a connotation of enforcing arrangements, not of volunteer arrangements.

The treaty might have different types. Analysing the content of JCPOA, it was noted that parties have intentionally avoided whatever terms that related this instrument to 1969 convention. This instrument does not have any signature, while all international treaties need to embody a signature in their final part. It is worth mentioning, by signature here it is meant a formal signature not a set of signatures signed by the negotiators on JCPOA cover page. This is because, technically speaking, these signatures are not included in a set of factors for transforming an instrument to a treaty. It must be noted that, in JCPOA, use has been made legal terms which were not used in 1969 Convention. On this basis, negotiators' insist on no use of terms in the mentioned convention is something that affirms the notion that the negotiators have never wanted that results of nuclear negotiations be an international treaty. They have been put instead of signature and use has been voluntarily made of the term 'finalization day'. Basically, use is made of 'ratification' in treaties while this instrument has under no condition made use of the term 'ratification' which is a common term in treaties. It is interesting to note that the day when JCPOA was approved will be 90 days after approval of UN Security Council's resolution. That

72. "1- "Finalization Day is the date on which negotiations of this JCPOA are concluded among the E3/EU+3 and Iran, to be followed promptly by submission of the resolution endorsing this JCPOA to the UN Security Council for adoption without delay."

2-“Adoption Day is the date 90 days after the endorsement of this JCPOA by the UN Security Council, or such earlier date as may be determined by mutual consent of the JCPOA participants, at which time this JCPOA and the commitments in this JCPOA come into effect. Beginning on that date, JCPOA participants will make necessary arrangements and preparations for the implementation of their JCPOA commitments"

3-"Implementation Day is the date on which, simultaneously with the IAEA report verifying implementation by Iran of the nuclear-related measures described in Sections 15.1. to 15.11 of Annex V, the EU and the United States take the actions described in Sections 16 and 17 of Annex V respectively and in accordance with the UN Security Council resolution, the actions described in Section 18 of Annex V occur at the UN level."

4-“Transition Day is the date 8 years after Adoption Day or the date on which the Director General of the IAEA submits a report stating that the IAEA has reached the Broader Conclusion that all nuclear material in Iran remains in peaceful activities, whichever is earlier. On that date, the EU and the United States will take the actions described in Sections 20 and 21 of Annex V respectively and Iran will seek, consistent with the Constitutional roles of the President and Parliament, ratification of the Additional Protocol."

5-"UN Security Council resolution Termination Day is the date on which the UN Security Council resolution endorsing this JCPOA terminates according to its terms, which is to be 10 years from Adoption Day, provided that the provisions of previous resolutions have not been reinstated. On that date, the EU will take the actions described in Section 25 of Annex V."'”

73 - "The full implementation of this JCPOA will ensure the exclusively peaceful nature of Iran's nuclear programme."

${ }^{74}$ “" Iran reaffirms that under no circumstances will Iran ever seek, develop or acquire any nuclear weapons.”

75 - "The E3+3 will submit a draft resolution to the UN Security Council endorsing this JCPOA affirming that conclusion of this JCPOA marks a fundamental shift in its consideration of this issue and expressing its desire to build a new relationship with Iran. This UN Security Council resolution will also provide for the termination on Implementation Day of provisions imposed under previous resolutions; establishment of specific restrictions; and conclusion of consideration of the Iran nuclear issue by the UN Security Council 10 years after the Adoption Day." 
is, JCPOA would be enforcing without interruption of states' authorities. Moreover, this instrument does not include the guarantee of a treaty. Guarantee is a person or organization who receives instruments approved by the states so as to find out how many countries joined the treaty. While there exists a guarantee in all treaties who receives all the approved instruments. All modern treaties are entered into action when they have the ultimate number. It is not necessary that all the countries approve it in their state's systems. This instrument is not such. It has no minimum to be approved by the states. So, this witting on the part of the parties indicates that they have avoided to leave the slightest trace of themselves in the instrument so as to include a sense of being a treaty in it. The third element in the international arena is the notion if this instrument is assumed a treaty, then it must be published as a sub-category of UN documents; but such a thing never happened for this instrument because this instrument is a part of UN resolution. It was the very time a treaty attached a resolution.

\section{Parties' Intention and Satisfaction}

Jurists have constantly noted parties' intention and satisfaction. According to this viewpoint, only when an international instrument is considered a treaty that treaty parties' intention is making a treaty. However, during the last 18 months of Iran's negotiations with 5+1, all the parties reaffirmed that the ultimate instrument is not an international treaty. This was not limited to the time of negotiation and, even after concluding the negotiations, Americans stated that this instrument is NOT a treaty. It seems that Iran's Foreign Ministry had the same idea during the negotiations: JCOPA instrument is not a treaty.

MohamadJavad Zarif, Iranian foreign minister, make a note on JCPOA approval in the parliament: "I believe that is not an international treaty which might need approval in the parliament. As a person who has taught law for a while, I propose that JCOPA is in fact the method of managing a number of UN resolutions, terminating other resolutions by one resolution and indicates what must be done now. As the name speaks for itself, JCOPA is a joint comprehensive plan of action, because you have a number of resolutions that want to put them next to one another, but how? This shall be done in the sense that a new resolution has emerged which has terminated many of the previous resolutions and that a part of these methods presented in JCPOA is agreed upon; and the resolution itself is far from this agreement. However, this is a method which puts this method into force. Therefore, legally speaking, this is not an agreement. That is why those fellows who question about this international agreement, ask why it does not a have a Persian translation! Initially they believed that this agreement was international. Of course, when there is a two-dimensional treaty you need to have a Persian version and a version of another language; but this has not been the case. This was not a treaty so you might have a Persian and an English format. This was a plan we agreed upon with 6 other countries to solve a problem, within a framework, that existed in implementation of our previous commitments as a member of UN and NPT (which we know them illegal and illegitimate) within a framework. This framework is in fact a framework which is not to be used for previous problems and it is not an international agreement which requires approval" ${ }^{76}$

\section{Conclusion}

Compacts between sovereignties are phenomena that have always existed in the history. The concept of treaty entered into international relations literature from first of $19^{\text {th }}$ century and had significant effects on development and growth of collaboration and correlation between the states. Treaty, in the sense of an agreement between subjects of international law which include rules of international law, has gone through different temporal and historical passages. So it has experienced many different principles, rules and elements through these ups and downs. Among these elements, reference can be made to written form of the agreement, being made between subjects of international law, being included in international rules and obligations, its approval in parties' state law, setting a guarantee for that, submission to UN secretariat and some other formal and content elements. Nevertheless, it has also been slightly effected by general legal rules including parties' intention in the content and position of treaties and agreements in the international legal law. As we know, controversy between treaties and other agreements is of great importance. This is because, setting an instrument as a treaty or agreement might precede many prerequisites and different elements. In addition, it would result in many effects in the international arena and the relationship between its members.

To distinguish between these documents, many factors have been presented; intention being the most important one. Intention can be figured out through many symptoms including direct presentation in the instrument, shape and name of the instrument (though, generally, shape and name of the instrument are not enough), theatmosphere, etc.

After Iranian Islamic Republic in 1979, nuclear plan in Iran was a locus of international challenges and clashes,

\footnotetext{
${ }^{76}$ - http://shahrara.com/page, 1394,5,31,8,01.html
} 
which resulted in impose of sanctions by European and American countries under the $8^{\text {th }}$ season of UN charter and repeated resolutions out by the Security Council. Finally, after 13 years of negotiation, an agreement was made with the title of Joint Comprehensive Plan of Action (JCPOA) which put an end to these challenges.

Investigation of the atmosphere of this agreement, along with negotiators' comments and the involved foreign ministers, guides us to draw the conclusion that, disregard of what kind of instrument it is, JCOPA cannot be a treaty at all. Among the reason for claiming this, mention can be made of:

Starting part of preamble of JCPOA makes clear a situation and does not create a liability or situation. In the next paragraph, this is reaffirmed through a condition. After that, in the beginning of the introduction and general provisions and also in clause 1, we face a piece of text which adds a new position or situation to JCPOA and it is dependency of JCPOA on affirmation by the Security Council that indicated attachment of JCPOA to Security Council resolution. In other terms, what took place was negotiating for preparation of a draft for the Security Council's resolution and if there exists a commitment, it is emerged from the resolution and not the JCPOA instrument itself. Moreover, analysis of part 34 in JCPOA and its related clauses makes us more certain about the fact that JCPOA is not an international treaty.

In preamble and general provisions, there exists other symptoms on this claim including no formation of a procedure for another state. The most important part is the last line of preamble and general provisions which clearly talks about the volunteer sense of JCPOA. However, rules and obligations of international treaties are international arrangements and not volunteer ones.

All in all, as it was mentioned, making use of unpopular legal terms of 1969 Convention, no formal signature, no guarantee to the treaty, no valedictory of JCPOA in UN secretariat and other points can be included asresolute reaffirmation of this claim. In addition to all the above points, attention needs to be paid to the intention the negotiators and representatives about whether JCPOA is deemed a treaty or not. In this respect, reference can be made to parties' ideas as stated in the media.

\section{References}

"IAEA GOV/2003/40: Implementation of the NPT safeguards agreement in the Islamic Republic of Iran", Retrieved 20 September 2009

"IAEA Report for military dimensions, see pages 4-12", International Atomic Energy Agency. 8 November 2011. At: http://www.isis-online.org/uploads/isis-reports/documents/IAEA_Iran_8Nov2011.pdf

"Iran Affairs: Blasts from the Past: Western Support for Iran's Nuclear program". 2008. Retrieved 24 February 2008. at: http://www.iranaffairs.com/iran_affairs/2006/05/blasts_from_the.html

"Signatories of the Biological Weapons Convention", Retrieved 23 November 2011, at: http://www.opbw.org/convention/status.html

Aust, A. (1986). The Theory and Practice of Informal International Instruments. International \& Comparative Law Quarterly, 35.

Delaume, G. R. (1962). The Proper Law of Loans Concluded by International Persons. American Journal of International Law, (56).

Eisemann Le, P. M. (1979). Gentlemen's Agreement' comme source de droit international. JDI, 106.

Fawcett. (1953). The Legal Character of International Agreements. British Yearbook of International Law, (30).

Gamble, J. K. (1980). Multilateral Treaties: The Significance of the Name of the Instrument. Interdisciplinary Law Journal, 10, California Western.

Garcia, M. J. (2010). International Law and Agreements: Their Effect Upon U.S Law. Congressional Research Service. Retrieved from http://www.fas.org/sgp/crs/misc/RL32528.pdf.

Harvard Draft

Hollis, D. B., \& Newcomer, J. J. (2009). Political Commitments and The Constitution. Virginia Journal of International Law, 49(3).

ICJ Reports, (1961), Temple of Preah Vihear Case (Cambodia v. Thailand).

ICJ Reports, (1974), Nuclear Tests Cases (Australia v. France and New Zealand v. France).

ICJ Reports, (1978), Aegean Sea Continental Shelf Case (Greece v. Turkey).

ICJ Reports, (1994), Maritime Delimitation and Territorial Questions Between Qatar and Bahrain (Qatar v. 
Bahrain).

ICJ Statute

IDI , International Texts of Legal Import in the Mutual Relations of Their Authors and Texts Devoid of Such Import, Session of Cambridge, 1983.

International Covenant on Civil and Political Rights.

Jennings, R., \& Watts, A. (Eds.). (1996). Oppenheim's International Law (Vol. 2, 9th ed.). London, Longman.

JW. (1996). Head Evolution of the Governing Law for Loan Agreements. American Journal of International Law, (90).

Kerr, P. K. (2010). Iran's Nuclear Program: Status. Congressional Research Service.

Khan, S. (2010). The study case: Iran. Iran and nuclear weapons. Routledge Global Security Studies.

Klabbers, J. (1996). The Redundancy of Soft Law. 65 Nordic JIL.

Klabbers, J. (1998). The Concept of Treaty in International Law. Netherlands, Kluwer Law.

Mc nair. (1961). The law of treaties. Oxford.

Michalowski, S., \& Bohoslavsky, J. P. (2009). Ius cogens, Transnational Justice and Other Trends of the Debate on Odious Debts: A Response to the World Bank Discussion Paper on Odious Debts. Columbia Journal of Transnational Law, 48.

Myers, D. P. (1957). The Names and Scope of Treaties. American Journal of International Law, (51).

Nguyen Quoc Dinh, Dailler, P., \& Pellet, A. (1987). Droit international public. Librairie générate de Droit et de Jurisprudence, 3rd edn., Paris.

Rebecca M. M. Wallace, Olga Martin-Ortega. (2009). International law. Sweet \& Maxwell.

Retrieved 17 April 2006. At: https://fas.org/nuke/control/npt/text/npt3.htm

Retrieved 22 July 2008. At: https://www.opcw.org/about-opcw/member-states/

Reuter, P. (1972). Introduction au droit de traites. Armand colin, Paris.

Roe, S. (2007). An atomic threat made in America. Chicago Tribune.

Seidl-Hohenveldern, I. (1975). The Theory of Quasi-International and Partly International Agreements. Revue Belge de Droit International, (11).

U.S. Department of State, Guidance on Non-Binding Documents, http://www.state.gov/s/1/treaty/guidance

UN Treaty Handbook. (2001).

Vattel, E. de. (1758). Le droit des gens. book II ch XII Sects. 152, 154 (CG Fenwick translation (1916) 160).

Widdows, K. (1979). What Is an Agreement in International Law? British Yearbook of International Law, 50.

Yearbook of the International Law Commission (1950), vol. II.

Yearbook of the International Law Commission (1953), vol. II.

Yearbook of the International Law Commission (1956), vol. II.

Yearbook of the International Law Commission (1966), vol. II.

Yearbook of the International Law Commission 49. (1962).

\section{Copyrights}

Copyright for this article is retained by the author(s), with first publication rights granted to the journal.

This is an open-access article distributed under the terms and conditions of the Creative Commons Attribution license (http://creativecommons.org/licenses/by/3.0/). 